\title{
Legal Precedent as a Source of Law from a Legalistic Perspective: Comparative Legal Analysis of Anglo-American and Continental Law Enforcement Models
}

\author{
Olga I. Miroshnichenko ${ }^{1} \&$ Petr I. Chugunkov ${ }^{1}$ \\ ${ }^{1}$ Theory and history of law department, Law School, Far-Eastern Federal university, Vladivostok, Russian \\ Federation \\ Correspondence: Olga Miroshnichenko, Anisimova str., 15-19, 690003, Vladivostok, Russian Federation. Tel: \\ 7-914-790-9213. E-mail: Olga-star.05@mail.ru
}

Received: January 17, 2015 Accepted: February 16, 2015 Online Published: May 14, 2015

doi:10.5539/res.v7n7p1 URL: http://dx.doi.org/10.5539/res.v7n7p1

\begin{abstract}
In this article the authors are analyzing different approaches to understanding of legal precedent as a source of law in formal sense. The authors think that the essence of the precedent should be deeply studied in legal science. As a conclusion authors suggest that there can be distinguished two main models of legal precedent: Anglo-American and civil models. And the role of the legal precedent in each concrete country should be analyzed according to these two models.
\end{abstract}

Keywords: legal precedent, judicial practice, common law, lawmaking

Disputes about whether legal precedent can be considered as a source of positive law are crucial for Russian juridical science. In our opinion, many papers attempting to grasp this issue are encumbered with many inaccuracies resultant mostly because of the unwillingness of their authors to explore the nature of the precedent as a legal phenomenon. The latter is impossible without deep etymologic analysis of the notion and its evolution in the states where it was created and developed.

In our opinion, analysis of judicial practice and summary of judicial statistics drawn from legal systems of developed states from Romano-Germanic legal family today demonstrate that rulings of supreme courts that are supposed to be only official interpretation of laws, are in fact used as legislative instruments. The only question is if this situation, doubtless taking place in the real Romano-Germanic world (italics is added by $O . M$., P. C.), accords to the classic Anglo-American doctrine of the legal precedent. In other words, do analysis and summary of the judicial practice embody legal precedent as it is understood in the countries of Anglo-Saxon legal family? In our opinion, answering this question requires thorough comparative legal analysis of the nature and role of the legal precedent in the modern English and American legal systems.

So, currently many approaches to interpreting nature and role of a legal precedent are offered by various legal systems. So-called case-law or common law emerged in England. As in "classic English model", legal precedent as a legal provision is formed "outside the law" - extra legem or "against the law" - contra legem (Pound, 1999). For example, English researcher Rupert Cross emphasized the following rules of an English precedent:

1) A legal precedent cannot be set by any court, but only by a supreme court.

2) Each court must follow rulings of a superior court and Courts of Appeals (except for House of Lords) are bound by their previous rulings. A legal precedent is compulsory, since English courts must follow the rulings made earlier even if there are strong arguments, which could have otherwise allowed avoiding it.

3) Execution of justice must proceed on the premise that similar cases must be settled similarly.

4) A legal precedent is the essence of a ruling; the rest is "obiter dicta" (Cross, 1985).

In English common law a legal precedent is based on three main principles:

1) Stare decisis - the principle that stipulates compliance with legal precedents.

2) Ratio decidendi- the part of a court ruling or the essence of the judge's legal opinion on which the ruling is based. 
3) Obiter dicta are arguments that are not crucial for the court's conclusion on the case. They are defined as "said in passing". The judge's responsibility for a formulated legal precedent depends on its power in future which is closely related to hierarchy of courts: a passed ruling becomes legal practice at some courts and a legal precedent at other courts (Perell, 2014).

The aforementioned English model of a legal precedent is classic and is not implemented in any other country of Anglo-Saxon legal family in its pure form today.

For example, US Federal Supreme Court and supreme courts of the states are not bound by the rulings they have created earlier and are not obliged to follow them (Chirkin, 2004). US judicial system consists of two parts-federal judicial system and judicial system of the states. Both of them settle cases relegated to them. Federal system includes US Supreme Court, courts of appeals and county courts, special courts. However, federal system is not viewed as superior to the state judicial system (except for the US Supreme Court) (Bogdanovskaya, 2002). Thus, two aforementioned systems are independent. Concerning the rulings of states' supreme courts, in 1938 US Supreme Court officially stated that there is no federal case law, as well as that states are not bound by one another's legal precedents (Tompkins, 1938). However, in accordance with the American Constitution being the supreme judicial authority US Supreme Court is entitled to overrule any court ruling if it contradicts constitutional provisions (Zhidkov, 1985).

American legal practice has seen legal precedents die away when their further application was unreasonable. Case "Brown v. Education of Topeka" (Brown v. Education of Topeka) is most frequently used to illustrate this option. In spite of the precedent "Plessy v. Ferguson" that formalized separate education of white and Afro American citizens, US Supreme Court once stated that this educational method was unconstitutional since it undermined equality of American citizens, i.e., in the USA regulations set by legal precedents can be substituted with appropriate regulations that better fit imperatives of the time depending on social, economic and probably even political changes.

Thus, though USA had initially adopted classic English law, it eventually created its own specific model of the rule of law-unique American legal precedent system. In fact, along with the function of law enforcement American judges are entrusted with lawmaking. In its turn, derogating importance of statute law in USA is unjustified. First of all, American legislation is externalized in the main law of this state-it's constitution that sets all the main principles of American legal system and has a direct effect on every part of it. This can be proved by the court's ability to use text of Constitution (Kanankina, 2009) when they are deciding a case. Secondly, federal laws and laws of the states play a significant role in regulating social relations in the USA; these laws contain provisions that must be complied with by subjects they apply to. Thus, we can see dualism of main sources of law in the American legal system: on the one part, legal precedent is typical for Anglo-American legal family to which USA belongs conceptually; on the other hand the role of laws and other legal provisions in regulating life of American society cannot be denied. It also should be mentioned that if there is no appropriate legal precedent or law, courts base their rulings on the existing scientific doctrines and general principles of law (Kanankina, 2009).

So, in USA precedent as a source of law from legalistic perspective is treated simpler compared to classic English model, i.e., judicial practice can be changed.

Canada is a perfect example of a country where two opposite legal algorithms coexist. Specifics of its legal system is that on the one hand it belongs to Anglo-American legal family of common law and uses legal precedent as an important source of law, on the other hand Canadian legal system was significantly influenced by codified law in course of its development. For example, Criminal Code of Canada (Criminal Code of Canada) and Labor Code of Canada were enacted in 1985; many issues relating to civil law are regulated at the level of federal legislation as well.

Currently main source of Canadian law is statute law. Case law (common law) functions along as a complex of legal regulations created by judges in course of law enforcement. Thus, a legal precedent can state new common law principle or interpret the law. However, as R. Cross said, a legal precedent is subordinated to legislation since a statute can always overrule it (Cross, 1985). At the same time, legal precedents are able to solve a specific issue that is not regulated by the law through interpreting and explaining legal principles.

In particular, priority of statute over common law is proved by the Canadian criminal law. It is banned to convict on criminal offense for crimes stipulated by common law (Vedernikova \& Suleymanova, 2013). Despite that, rulings of Canadian high court are still binding for subordinated courts, except for cases where there are compelling reasons to digress from a legal precedent. In such situations a precedent formulated earlier can be substituted by the ruling of a superior court or a court of the same level if the latter has the respective jurisdiction. 
In most cases courts prefer not to overrule legal precedents but to change it referring to differences in facts, so a legal precedent has become flexible and adapted to changing context (Marchenko, 2002).

Analysis of magisterial law, judicial practice, interpreting certain legal regulations by the Supreme Court are emphasized in Canada due to peculiarity of Canadian legal model.

However, despite that a legal precedent has limited significance in the Canadian system of sources of law, it is highly important for functioning of the country's judicial system (Gall, 1983).

In the countries of Romano-Germanic legal family, including Russia, statutes still dominate-they contain main legal principles and are supposed to be main sources of the law.

Legal provisions of the modern Romano-Germanic law have been treated logically and scientifically to achieve wide generalization with an implied goal, however vague or formalistic it might be. A legal provision is a rational deed and a product of legislative power that can effectively summarize "common will" of people, state and its authorities in a legal provision. Court applies abstract legal provisions to specific situations, resolving certain issues in accordance with shared provisions, i.e. interprets it (Aranovaky \& Knyazev, 2013). The growing role of courts' legal opinion in regulating social relations is more and more often named "precedent"-it accords with principles of the modern case law in Anglo-American legislation" (Neshataeva, 2012).

Above we have analyzed the existing contemporary approaches to understanding legal precedent as a source of law from a legalistic perspective. We deem that the English "rigorous" model and the American "soft" one are currently dominating. Operation of a legal precedent as a source of law from legalistic perspective in the countries of Romano-Germanic group also rises no doubt. In our opinion this model is not either the first or the second, but a separate individual one.

Thus, if we bring these two models together under the term "precedent", taking into account their essential difference, we can distinguish between two notional types of a precedent: continental model of judicial practice and Anglo-American legal precedent.

In our opinion, we should make an analysis of the role of a legal precedent as possible or actually existing source of positive law in the modern Russian legal system based on clear distinguishing between the models mentioned above.

\section{References}

Aranovaky, K. V., \& Knyazev, S. D. (2013). Fate of legal precedent on Romano-Germanic law (No. 4. pp. 30-39). Constitutional court of the Russian Federation.

Bix, B. (2003). Jurisprudence: Theory and Context (pp. 145-149).

Bogdanovskaya, I. Y. (2002). Legal precedent as a category of "common law". In Law and politics (No. 7, pp. 17-21). M.: Yurist.

Brown v. Education of Topeka. (2014). Cornell University Law School. Retrieved November 7, 2014, from http://www.lawschool.cornell.edu/international/study_abroad/paris_summer/admitted-students/Comparative -Law-and-Social-Science/loader.cfm?csModule $=$ security/getfile\&PageID $=69940$

Chirkin, V. E. (2004). Constitutional law of foreign countries (p. 201). M.: Yurist.

Civil Remedies Act of 2001. (2014). Web-site of Ministry of Justice of Canada. Justice Laws Website. Retrieved November 7, 2014, from http://www.e-laws.gov.on.ca/html/statutes/english/elaws_statutes_01r28_e.htm

Criminal Code of Canada 1985. (1985a). Web-site of Ministry of Justice of Canada. Justice Laws Website. Retrieved November 7, 2014, from http://laws-lois.justice.gc.ca/eng/acts/C-46/index.html

Criminal Code of Canada 1985. (1985b). Web-site of Ministry of Justice of Canada. Justice Laws Website. Retrieved November 7, 2014, from http://laws-lois.justice.gc.ca/eng/acts/L-2/index.html

Cross, R. (1985). Precedent in English Law (pp. 151-154). M.

Cross, R. (1985). Precedent in English Law (p. 167). M.

Cross, R., \& Harris, J. W. (1991). Precedent in English Law (p. 3).

Erie, R. Co. v. T. (1938). Cornell University Law School. Retrieved November 7, 2014, from http://www.lawschool.cornell.edu/

Gall, G. L. (1983). The Canadian Legal System (2nd ed.). Toronto: Carswell Legal Publications.

Kanankina, E. S. (2009). Legal system of the United States of America. In International public and private law 
(No. 1, pp. 40-48). M.: Yurist.

Marchenko, M. N. (2002). Course of comparative law (pp. 672-675). M.

Neshataeva, T. N. (2012). Legal precedent and human rights. In Comparative constitutional review (No. 5, p. 62).

Perell, P. M. (2014). Stare decisis and techniques of legal reasoning and legal argument. Retrieved November 11 , 2014, from http://legalresearch.org/writing -analysis/stare-decisis-techniques/

Plessy v. Ferguson 1896. (2014). Cornell University Law Scholl. Retrieved November 7, 2014, from http://www.lawschool.cornell.edu/international/study_abroad/paris_summer/admitted-students/Comparative -Law-and-Social-Science/loader.cfm?csModule $=$ security/getfile $\&$ PageID $=69940$

Pound, R. (1999). The Spirit of Common Law (p. 182).

Vedernikova, O., \& Suleymanova, S. (2013). Role of a legal precedent in the system of source of Canadian criminal law. In Criminal law (No. 6, pp. 10-17).

Zhidkov, O. A. (1985). US Supreme Court: Law and politics: Study guide (pp. 97-100). M.: Nauka.

\section{Copyrights}

Copyright for this article is retained by the author(s), with first publication rights granted to the journal.

This is an open-access article distributed under the terms and conditions of the Creative Commons Attribution license (http://creativecommons.org/licenses/by/3.0/). 